\title{
Does fertilizer adoption enhance smallholders' commercialization? An endogenous switching regression model from northern Ethiopia
}

\author{
Menasbo Gebru Tesfay*
}

\begin{abstract}
Background: Theory of development economics emphasizes how individuals transit out of poverty. Adoption of improved agricultural technologies is one of the means that enables to facilitate the transition in developing countries. The application of yield-enhancing technologies is potentially likely to produce crop income more than what farm households consume compared to farming activities with more traditional production techniques. Inorganic fertilizer is one of modern agricultural technologies that can enhance agricultural productivity. However, the increase in crop production by itself is insufficient to improve the welfare of farm households; rather, it has to be linked to the market. Therefore, I am motivated to evaluate the potential impact of adoption of inorganic fertilizer on smallholders' commercialization as technological change enhanced land-use intensification and crop productivity in a land-scarce economy like in rural Tigrai, northern Ethiopia.
\end{abstract}

Methodology: The study utilizes cross-sectional farm household data collected in the 2014-2015 cropping season from a randomly selected 626 farm households in rural Tigrai, northern Ethiopia. Plot-level productivity is estimated using OLS with a control function approach. The causal impact of fertilizer adoption on smallholders' commercialization is estimated using an endogenous switching regression model to control for selection problems associated with adoption decision. While factors affecting the probability and extent of inorganic fertilizer adoptions are analyzed using a double-hurdle model (hurdle 1 for probability of adoption and hurdle 2 for the extent of adoption).

Results: The double-hurdle results show that large family size, a higher number of male and female adults affect positively and significantly adoption probability of inorganic fertilizer, while long plot distance, households headed by illiterate are key constraints for inorganic fertilizer adoption. Fertilizer adoption has positive and significant effect on plot-level productivity. Finally, adoption of inorganic fertilizer has a strong and positive impact on smallholders' commercialization through productivity gain.

Conclusion: The finding of this study confirms the potential role of technology adoption in facilitating rural transformation as higher production from adoption of improved agricultural technologies translates into surplus products and greater ability to integrate with the output market.

Keywords: Technology adoption, Smallholder commercialization, Double hurdle, Endogenous switching, Ethiopia

*Correspondence: menasbo4gebru@gmail.com

Department of Economics, Mekelle University, P O Box 451, Mekelle, Ethiopia

\section{Background}

In contrast to the increment of demand for food in developing world in general and in Sub-Saharan Africa (SSA) in particular, smallholder agriculture is characterized

c) The Author(s) 2020. This article is licensed under a Creative Commons Attribution 4.0 International License, which permits use, sharing, adaptation, distribution and reproduction in any medium or format, as long as you give appropriate credit to the original author(s) and the source, provide a link to the Creative Commons licence, and indicate if changes were made. The images or other third party material in this article are included in the article's Creative Commons licence, unless indicated otherwise in a credit line to the material. If material is not included in the article's Creative Commons licence and your intended use is not permitted by statutory regulation or exceeds the permitted use, you will need to obtain permission directly from the copyright holder. To view a copy of this licence, visit http://creativeco mmons.org/licenses/by/4.0/. The Creative Commons Public Domain Dedication waiver (http://creativecommons.org/publicdomain/ zero/1.0/) applies to the data made available in this article, unless otherwise stated in a 
by low application of modern agricultural technologies and low crop productivity and high food insecurity [1, 2]. In reversing this, sustainable intensification of agricultural production becomes an important strategy for improving the livelihood, food security, and market integration of smallholder farmers [3]. Research and development interventions have attempted to improve the link between the development of new agricultural technologies and smallholders' market integration through productivity gain $([4,5]$.

The application of yield-enhancing technology is potentially likely to produce crops more than what farm households consume compared to farming activities with more traditional production techniques [6-9]. However, the increase in production itself is insufficient; rather, it should be linked to the market. This causal mechanism states that first farm households adopt modern agricultural technologies and improve plot-level productivity and generate surplus products. This surplus product will be exported to market for sale as households desire for a diverse consumption bundle and used to purchase other food and non-food items [6]. However, the unsolved question is as to what types of agricultural technologies are feasible and enable them to improve the expected payoffs in terms of income generation and market integration. In the case of weather uncertainty, degraded land, particularly in the semi-arid of Africa, the application of inorganic fertilizer presents an opportunity in reversing the rising trend of low agricultural productivity and food insecurity [4].

A number of studies have analyzed adoption determinants and impact of improved agricultural technologies on smallholders' commercialization [6, 10-16]. Despite this empirical evidence on the relationship between technology adoption and market, still, there are some gaps in the available studies.

First, previous studies apply the approach used to measure the level of commercialization, by considering a fraction of crops sold to the total crop income, which is commonly called marketed output $[13,17]$. However, this does not mean that farm households are self-sufficient in food consumption from own production and supply the surplus product to the market even if they adopt the yield-enhancing technologies. In this context, sellers of food crop are gross sellers and not net sellers and does not show whether a given household is food secured or not. The intuition is that a given household cannot produce all types of food crops required for home consumption, and there must be an exchange (sale and purchase of food grains) for a diverse consumption bundle. Then, finally, the household will end up either a net seller with a positive marketed surplus or a net buyer with a negative marketed surplus. Therefore, considering only the marketed output as an indicator of intensity of output market participation overstates the number of net sellers and understates the number of net buyer households, and lead to bias conclusion. Such argument was given less attention by previous works and the current study attempts to enrich the existing literature with a superior indicator of smallholders' commercialization using marketed surplus.

Second, adoption of agricultural technology facilitates market participation through productivity gain. However, computing of crop productivity (yield) by previous works Gebremedhin et al. [13], Khonje et al. [14], Tiamiyu et al. [15], Yesuf et al. [16] considered only the crop yield and gives less attention to by-products as part of crop income, and understate the value of crop income and gains from marketing of this by-product. In smallholder agriculture, however, adoption decisions of agricultural technologies not only depend on the expected gain from crop products, but also give attention to the expected gain from byproduct which is used as fodder for livestock.

Third, Asfaw et al. [18] assessed the impact of chickpea technology on smallholders' commercialization in Ethiopia and they found a positive result. While their study focuses on the agricultural potential areas of the country with less concern about food security and less likely to represent areas with lower agricultural potential where the issue of food security is vibrant. The study of Awotide et al. [19] assessed adoption determinants of improved rice variety and its impact on market participation of Nigerian rice producers using a censored tobit model and found a positive impact. However, the model estimation suffers from the endogeneity problem that access to the improved rice varieties is an endogenous regressor and lacks an attempt to fix the problem. Alene et al. [17] also, assess adoption determinants and the impact of inorganic fertilizer on marketed supply of Kenyan maize producers. However, determinants of inorganic fertilizer specification include wealth variables that are potential endogenous and give less attention to handle the endogeneity problem as well.

The link between technology adoption, particularly inorganic fertilizer and smallholders' commercialization is scanty or relatively thin in economic literature, especially in developing country settings where significant frictions make this question most silent. Therefore, the current study attempts to fill the aforementioned gaps and to achieve the following objectives. First, analyze the determinants of adoption and extent of adoption of inorganic fertilizer. Second, analyze the impact of fertilizer used on plot-level productivity and third, estimate the impact of inorganic fertilizer adoption on smallholders' commercialization through the productivity gain (crop and crop by-products) in highly populated 
and land-scarce economy using a regional representative farm household data.

From an econometric standpoint, adoption of fertilizer technology is analyzing using craggit double-hurdle model [probit model in hurdle 1 for probability of fertilizer adoption measured by the proportion of households decide to use the technology and truncation model in hurdle 2 for the intensity of fertilizer adoption measured by the amount of fertilizer used per hectare of land $(\mathrm{kg} /$ ha)]. Plot-level productivity is measured as the value of total crop income per hectare of land, and it is estimated using OLS with a control function approach to fix the problem of endogeneity sourced from the fertilizer used. While assessing the impact of fertilizer adoption on commercialization, it possesses two critical issues. The first issue is self-selection of technology adoption and varies among farm households. Untreated to this leads to self selection problem and creates bias impact estimation. Similarly, adoption decision is potentially an endogenous variable and creates an endogeneity problem in the market participation model due to unobservable time varying heterogeneity. In this paper, I apply an endogenous switching regression model to reduce the selection bias via controlling for both observed and unobserved heterogeneity.

\section{Review of empirical literature: technology adoption and market}

The relationship between technology adoption and market participation is complex [6]. Such relationship is characterized in terms of household perspective, where market participation is conceptually equivalent to technology adoption. This implies that the decision regarding technology choice is equal to decision to market participation. Success in productivity-based agricultural growth through adoption of modern agricultural technologies mainly depends on the prevalent of market opportunities [18]. Promoting smallholders' technology adoption is crucial and enhanced broader-based market participation through improving productivity and enhanced the amount of surplus products exported to the market for sale. For the present purpose, attention is due on the causal relationship between adoption of modern agricultural technology and smallholders' commercialization through productivity gain.

Agricultural commercialization is the process by which farm households are increasingly integrated into different markets such as input markets where agricultural technology is one among the others, food and non-food consumption markets, output markets and labor markets. The analytical portion of this paper, however, primarily focuses on the integration of smallholder farmers into output markets, as this is the typical indicator for the process of agricultural commercialization [11]. There are many factors that potentially affect market participation of crop producers such as extension services, infrastructure, and institutional service. However, in smallholder farming producing surplus products more than home consumption mainly through the application of modern agricultural technologies takes the greater share. In recent years, governments of developing countries including Ethiopia give high attention to promoting adoption of agricultural technologies and smallholders' commercialization so as to improve food security, economic growth and employment opportunity [18].

Different studies have analyzed determinants of adoption and impact of improved agricultural technologies on output market participation. For instance, Gebremedhin et al. [13] using cross-sectional data from Amhara region, Ethiopia, assessed the impact of inorganic fertilizer, agrochemical, and improved seed adoptions on smallholders' commercialization. The intuition is that application of agricultural technologies enhanced crop productivity, generated surplus products more than the home consumption, and supply the surplus to the market for sale. Accordingly, they found a positive impact. However, there are two methodological limitations observed in their study. First, technology adoption is an endogenous variable and treated it as a regressor leads to create a biased estimate. They use previous year access to extension service considered as an instrument for current period intensity of technology adoption while lagged variables are not strictly exogenous variables due to autocorrelation problem [20]. Second, intensity of market participation is proxy by marketed output instead of marketed surplus. Marketed output fails to show the net consumption (for a diverse consumption bundle of food grains through selling and purchasing of food crops) and is unable to characterize whether a given household is a net seller or net buyers of food crops.

The study of Alene et al. [17] assesses the impact of inorganic fertilizer on market participation of Kenyan maize supplier and they found a positive result. However, the study exhibits an identification strategy problem. This is in a disagreement that in the market participation model, an Inverse Millis Ratio was included to control the selection bias from fertilizer adoption, but failed to include the exclusion variable(s) in the first-stage fertilizer adoption estimation. Consistent with this, Asfaw et al. [11] reported a positive correlation between adoption of improved chickpea variety and the intensity of market participation by chickpea producers in the central highland of Ethiopia. Similarly, in Oromia regional state of Ethiopia, adopters of fertilizer and improved maize varieties are more likely to participate in maize market compared to the non-adopters [10]. In Nigeria, adopters 
of new rice seed variety greatly participate in rice output market compared to non-adopters [15]. Likewise, Barret et al. (2010) demonstrated that promoting adoption of farming technology has a positive effect on inducing broad-based output market participation in eastern and southern Africa. But, none of these studies attempt to show clearly whether the marketed output is a surplus measurement remaining after home consumption is fully met and is the net value of crop sold.

The review of related literature for this study reveals that there are no comprehensive studies that have systematically examined the impact of inorganic fertilizer adoption on smallholders' commercialization in Ethiopia. To fill this knowledge gap, this study attempts to assess empirically the impact of inorganic fertilizer first on plot-level productivity and then on smallholders' commercialization.

\section{Estimation method}

The model specifications below allow achieving three research objectives. First, analyze factors affecting adoption and adoption intensity of inorganic fertilizer using a double-hurdle model. Second, assess the impact of inorganic fertilizer adoption on plot-level productivity using OLS and finally the impact of fertilizer adoption on smallholders' commercialization using an endogenous switching regression model.

\section{Technology adoption decision}

Depending on the specific objectives of the studies, literature suggests various econometric techniques to modeling farmers' behavior of technology adoption decisions and identify the potential determinants $[1,11,12]$. Due to imperfect input and credit markets, poor employment opportunities in the formal labor market, smallholder farmers in developing countries made production and consumption decisions simultaneously. Such market failures may be drawn from underdevelopment of nonfarm sector, higher transaction costs, and asymmetric information. In this perspective, the importance of nonseparable household decisions between production and consumption become unquestionable [4]. In this paper, I follow the theoretical model of technology adoption used by Feder et al. [21] that farm households made adoption decisions under the conditions of input market imperfection, partial or missing credit and labor markets. Farm households expected to maximize their utility function subject to these constraints.

Assume $R=\left(\omega_{\mathrm{A}}-\omega_{\mathrm{NA}}\right)>0$, where $R$ is the dummy observable variable that takes the value of one for technology adopter, and zero for the non-adopter of the technology. The term $\omega$ denotes household benefits such as crop productivity, food security, and market participation. The subscripts (A) is for technology adopters and the (NA) is for technology non-adopters, respectively. The extent of inorganic fertilizer adoption decisions can be specified as [20]:

$$
\log R_{i}=\max \left(0, R *_{i}\right)+\beta^{\prime} X_{i}^{\prime}+U_{i}
$$

where the variable $R^{*}$ refers to the nonlinear specification of technology adoption equation one if a farmer " $i$ " uses the technology and zero, otherwise and $\log R$ is the logarithm form of technology used measured in kilogram per hectare of land conditional to adoption decision. I am interested in testing empirically in one specific technology, i.e., inorganic fertilizer adoption based on the following features. First, the regional government has a great commitment to agricultural growth through improving soil fertility and the technology is distributed almost in all of the region's agro-ecologies. Second, when relatively large number of smallholders adopted inorganic fertilizer, it gives enough information to investigate the adoption pattern of specific farm input. Third, analyzing adoption of this technology permits to waive the difficulty of controlling for difference across technologies (i.e., improved seeds may attribute to targeted agro-ecologies and adoption analysis of such technologies may lead to selection problem).

$X$ is a vector of explanatory variables. The choice of variables is based on adoption literature and their prior expectation effect on fertilizer adoption is presented in Annex Table 7 (see [21] for a detailed review). These variables include household-level characteristics such as gender, age, and literacy status of household head. Male, young and educated head households are expected to adopt inorganic fertilizer compared to female, elder and uneducated headed households. As farming, especially plowing with the help of oxen in the study region is more of male's tasks and females are less likely to practices in these activities. The productive human element of households expressed in terms of young and educated heads presents the capability of undertaking the laborious task, apply their effort in rapid adoption of modern agricultural technology and exploit new market opportunities. Households' endowment expressed in terms of land and non-land resource are expected to enhance the probability of fertilizer adoption decisions. The nonland resources comprise oxen and non-oxen livestock (in Tropical Livestock Units). An ox is one of the important farming inputs and encourages farmers to apply fertilizer adoption.

The non-land resource endowment variables and access variables like access to irrigation, information may not be strictly exogenous in fertilizer adoption. I run models with and without the potential endogenous variables to check how susceptible results are robust to this 
possible endogeneity. I also include plot-level characteristics such as soil quality, plot distance, owned farm size, and soil type. Farmers having plots with poor soil quality are expected to adopt fertilizer so as to improve soil fertility and ultimately increase plot level productivity. Households with large land size are more likely to adopt fertilizer technology due to the wealth effect. Households with far distance plots are less likely to adopt inorganic fertilizer due to high transaction costs associated with multiple treatment of fertilized plots. Community-level variables such as rainfall, population density, and the district dummies are also included in the adoption model. Rainfall is a complementary input to fertilizer application, and households residing in areas with sufficient rainfall are more likely to adopt fertilizer compared to households residing in areas with insufficient rainfall. Farmers live in a highly populated area are more likely to adopt fertilizer, indicating that land-use intensification improved plot-level productivity and enable to feed the growing population size. The dummy district is also part of the adoption model to capture fertilizer adoption differences across agro-ecologies. $U$ is the random error term with zero mean and constant variance.

The parameters of Eq. (1) for the intensity of fertilizer adoption (censored outcome variable measured in kilogram of fertilizer used per hectare of land) can be estimated using a censored tobit model. However, tobit model has two limitations. First, the probability of a positive value $(y>0)$ and the actual value $(y=0)$, are estimated jointly. Second, tobit model deals with restricted estimation approach imply that one variable explains equally the two levels of adoption decisions (probability and intensity of adoption). An alternative to tobit, for a corner-solution of dependent variable, Double-Hurdle (DH) model is more appropriate [22]. The merit of the DH model is flexible and enables us to estimate the outcomes of adoption and intensity of adoption in a separate process. The $\mathrm{DH}$ model also comprises two equations. The first equation deals with factors affecting the decision to adopt fertilizer using probit model (hurdle 1) and the second equation deals with factors affecting the intensity of fertilizer measured in $\mathrm{kg} /$ hectare of land use using truncation model (hurdle 2).

\section{Plot-level productivity}

Before doing any impact analysis of fertilizer adoption on smallholders' commercialization, I first try to see whether fertilizer use has any positive impact on plot-level productivity. To do this, I follow the empirical strategy adopted in Gebremedhin et al. [13] where they demonstrated the impact of the technology adoption on plot-level productivity and then on smallholders' commercialization. I have shown in the descriptive statistics section (see Table 3) that a significant number of households with fertilizer adoption earned higher per capita crop income compare to non-adopters. The argument behind adoption of fertilizer technology appears to be the gradual shifting from subsistence production to market-oriented production system and boosting the market integration of farmers. Thus, adoption of agricultural technology improves the market participation of farm households through productivity gain. This looks to be true when I look at my results in the descriptive section and the literature I have come across on this issue $[13,17,23]$. Yet, I need to verify if this is actually holding based on regression estimations as well. My argument here is that if fertilizer adoption affects positively and significantly plot-level productivity, there will be a possibility for it to affect smallholders' market participation as a net sellers of food crops. Therefore, plot-level productivity (monetary value of crop income per hectare) is a function of intensity of fertilizer used (logkg/ha), household features, endowments, plot and community-level characteristics, weather variables (rainfall and rainfall variability) and district dummy.

$$
\log Q_{i}=\varphi_{0}+\varphi_{1} \log R_{i}+\varphi_{2} X_{i}^{\prime}+\varepsilon_{i},
$$

where $Q$ refers plot-level productivity of household $i$ measured in monetary value of crop income per hectare of land. $X^{\prime}$ is a vector of control variables and their prior expected effect on plot-level productivity is presented in Annex Table 7 (see [13] for a detailed review). $\varepsilon$ is the error term with mean of zero and constant variance. The impact of fertilizer use on plot-level productivity is captured by the parameter $\varphi_{1}$ and is expected to be positive and significant. However, fertilizer adoption is a potential endogenous variable and untreated to the endogeneity problem creates biased impact assessment. This implies that there is a suspicion of correlation between the endogenous regressor (fertilizer use) and the error term, i.e., $\operatorname{cov}\left(\log R_{i} \varepsilon_{i}\right) \neq 0$ due to left out variables in the error term. The possible way of solving the endogeneity problem is using the instrumental variable method. Alternatively, for a linearly endogenous regressor, a control function approach relies on the similar kinds of identification conditions [20]. This means that Eq. (2) is specified separately into fertilizer adoption that is censored at zero (first stage) in Eq. (3) and plot-level crop productivity (second stage) Eq. (4), respectively, as follows:

$$
\begin{aligned}
& \log R_{i}=\alpha_{0}+\alpha_{1} Z_{i}+\alpha_{2} X_{i}^{\prime}+\mu_{i}, \\
& \log Q_{i}=\Gamma_{0}+\Gamma_{1} \log R_{i}+\Gamma_{2} X^{\prime}{ }_{i}+\Gamma_{3} \widehat{\mu}+\epsilon_{i} .
\end{aligned}
$$


The control function approach requires an exclusion restriction variable(s) $Z^{\prime}$ in the instrumentation Eq. (3). These have to be uncorrelated with the error term in Eq. (4) $\operatorname{cov}\left(Z^{\prime}, \epsilon_{i}\right)=0$, while correlated with the endogenous variable $\operatorname{cov}\left(\log R_{i}, Z^{\prime}\right) \neq 0$ in Eq. (3). Equation (3) is estimated using a censored tobit model while Eq. (4) is estimated using ordinary least square (OLS) model with bootstrapping standard errors to account for second stage estimation. The error term generated from tobit model estimation $(\widehat{\mu})$ is then included as a regressor in Eq. (4). The statistical significance of the residual provides a test for endogeneity of the fertilizer adoption. As in a twostage instrumental variable model, the control function approach requires exclusion restrictions as discussed above. In this case, distance to plot from homestead was used as an instrument. The intuition is that remoteness to plot could be one of the important reasons for dis-adoption of agricultural technology. This is because fertilized plots need multiple treatments and create high transaction costs due to high frequency of going and back to plot. Thus, households may decline to use fertilizer on far distant plots. I test the statistical validity of this by including the instrument in the plot-level productivity in one specification. If the instrument was insignificant in the plot-level productivity model but significant in the adoption model, and if the error term from the first stage model (the difference between the observed intensity and predicted fertilizer use) was significant in the plot-level productivity model, then endogeneity is an issue and was corrected for with the control function.

\section{Impact of technology adoption on smallholders' commercialization}

Considering the variable of interest, i.e., marketed surplus is a linear function of observable variables and the treatment variable of fertilizer use, the linear regression equation is specified as:

$$
\mathrm{MS}_{i}=\pi_{0+} \pi_{1} R_{i}+\pi_{2} Y_{i}^{\prime}+\epsilon_{i}
$$

where MS is the level of commercialization proxy by marketed surplus. On a typical farm household, major part of farm production (crop and crop by-products) is retained for various purposes. The first important purpose is for family's consumption. The second purpose is the feed requirement for farm animals. Selling some portion of crop output to repurchase other food grains for a diverse households' consumption bundle is the third purpose. Thus, the value of crop income remaining after these deductions is the marketed surplus. This approach is the broad-base definition of the net-seller/net-buyer/autarky status of households (Pavelescu [24]) and reformulated as follows:

$$
\begin{aligned}
\mathrm{MS}_{i}= & \left(\sum_{k=1}^{q} Q_{k i}\right)-\left[\left(\left(\sum_{k=1}^{c} C_{k i}\right)+\left(\sum_{k=1}^{s} S_{k i}\right)\right.\right. \\
& \left.\left.-\left(\sum_{i=1}^{p} P_{k i}\right)-\left(\sum_{i=1}^{f} F_{k i}\right)\right)\right],
\end{aligned}
$$

where MS is the monetary value of marketed surplus of household. $\sum_{k=1}^{q} Q_{k i}$ refers to total value of crop income (output of all crops and their by-products excluding livestock products) of the production year. $\left(\sum_{k=1}^{c} C_{k i}\right)$ is the total value of own crop output consumption. $\left(\sum_{k=1}^{s} S_{k i}\right)$ is the value of a portion of crop income sold to purchase other food grains that home cannot produce in the production year. $\left(\sum_{i=1}^{p} P_{k i}\right)$ is total value of purchased food grain from the market for home consumption, and $\left(\sum_{i=1}^{f} F_{k i}\right)$ denotes total value of feed for farm animals. $i$ and $k$ refer to the household and crop-type identifiers, respectively. Based on this, farm households would like to participate in one of the market regimes: if MS $>0$, a household is a net seller of food grain and food secured from own crop production. If $\mathrm{MS}<0$, a household is a net buyer of food grain and food insecured from own crop production. This approach nets out the value of crop products sold and explains whether a given household is food secured or not.

$R$ in Eq. (5) is a variable of interest where $R=1$, household $i$, adopts fertilizer, and $R=0$ otherwise. $Y^{\prime}$ is a vector of explanatory variables that affect marketed surplus and variables choice is based on market participation literature (see [25] for a detailed review). Their prior expectation is presented in Annex Table 7. These variables include household demographics, endowment, spatial and community-level variables. It is expected that male and literate headed households are more likely to use to modern agricultural technologies, capture higher crop productivity, and therefore they are more likely to participate in the output market as a crop seller with higher intensity. The intuition is that households exhibit better farming capacity and access to information pertaining to the benefit of technology and market opportunities. In developing countries including Ethiopia, factor markets are imperfect [26]. Under such circumstances, resource endowments proxy by oxen, and non-ox livestock and access variables such as access to irrigation are expected to adopt agricultural technologies and then to have higher crop productivity and higher market participation [13]. Moreover, households who have access to information proxy by ownership of communication devices such as radio, mobile phone, and television improves market efficiency 
through reducing transaction costs and enhanced the bargain position of smallholders on market participation [27]. Therefore, it is expected that households access to market information are more likely to participate in selling of their crops at lower transaction costs. Spatial variable proxy by distance to market and road affects variable marketing costs $[25,28]$. Thus, it is expected that households that are far distant from market and all weather roads have lower probability of technology adoption and decline to participate in the output market due to remoteness. $\in$ is the unobservable effect of the model assumed with zero mean and constant variance. The impact of fertilizer adoption on the outcome variable is measured by the parameter $\pi_{1}$. This approach, however, might generate biased estimates due to the self-selection problem in fertilizer adoption. The challenge here is whether technology adoption expects to have an average impact over the entire sample of farm households through the intercept shift or through shifting the slope in the marketed surplus by raising crop productivity. If I used pooled model estimation, it is assumed that control variables would have the same impact on adopters and non-adopter and generate common slop for both regimes. However, I assume that a vector of control variables have differential effect on marketed surplus for adopters, and non-adopters and have to be specified separately and fix the problem of endogeneity. This econometric challenge generated from observable and unobservable heterogeneity and motivates to use the endogenous switching regression model to account endogeneity and self-selection problems [1]. A detailed explanation about the endogeneity problem and its remedial is presented in the section below.

\section{Impact evaluation strategy: an endogenous switching regression model}

Following Singh et al. [29], the non-separable farm household is a producer-consumer where consumption and production decisions are practiced simultaneously. This simultaneous decision also enables to express the relationship between production and market participation. The non-experimental method of impact evaluation constructs group of technology adopters and technology non-adopters for comparison purposes. The adopter group is, on average the same in all of the other factors to the non-adopter group except technology adoption [30].

The focus of this study is to analyze the impact of fertilizer adoption on smallholders' commercialization. But, due to the causal effect builds on survey data, it may face a counterfactual problem. The point is what I cannot observe the marketed surplus for fertilizer adopters, in case they did not adopt. Thus, market participants will be different; implies some households are fertilizer adopters and the others are fertilizer non-adopters. Given the observable characteristics, the treatment effect equation is presented as in Eq. (5) above.

Fertilizer adoption is a potential endogenous regressor and OLS estimation creates biased results. On the other hand, instrumental variable method is suitable to deal with potential endogeneity problems. Nonetheless, I have not found yet how to "instrument" potential endogenous regressors and correct potential endogeneity problems for nonlinear models as IV method seems to be well developed for linear models. Hence, the endogenous switching regression model is used to correct the endogeneity problem by estimating two separate selection equations (i.e., with and without technology adoption):

$$
\text { Regime 1: }\left(\mathrm{MS}_{1} \mid R_{i}=1\right)=\beta_{1} Y_{i}^{\prime}+E\left(\varepsilon_{1}\left|u_{i}\right\rangle-\gamma y\right),
$$

Regime 2: $\left(\mathrm{MS}_{0} \mid R_{i}=0\right)=\beta_{0} Y_{i}^{\prime}+E\left(\varepsilon_{0} \mid u_{i} \leq-\gamma y\right)$.

$\mathrm{MS}_{1}$ and $\mathrm{MS}_{0}$ are marketed surplus with and without fertilizer adoption, respectively. $Y^{\prime}$ is a vector of explanatory variables that explain marketed surplus. $\gamma, \beta_{1}, \beta_{0}$ and are parameters to be estimated for the selection, outcome with adoption and outcome without adoption estimations, respectively. The estimation method generates three random error terms of $\varepsilon_{0}, \varepsilon_{1}$ and $u_{i .}$. For the endogenous switching regression model to be identified, some variable(s) in the adoption model needs to contain a selection instrument in addition to those generated by the non-linearity of the selection model of adoption. Plot distance from homestead is considered as instrumental variable and used for the identification of the impact of fertilizer adoption on the marketed surplus variable. The intuition is that farmers having far distant plot from homestead discourages technology adoption due to remoteness as fertilized plots need regular follow-up with high transaction costs. I consider that the variable is likely to be correlated with the adoption of inorganic fertilizer, but is unlikely to influence the outcome variable directly or correlated with the unobserved errors. Thus, the conditional expectation of the outcome variable is defined as:

$$
\begin{aligned}
& E\left(\mathrm{MS}_{1} \mid Y_{i}^{\prime} R_{i}=1\right)=\beta_{1} Y_{i}^{\prime}+\delta_{1 u} \lambda_{1}, \\
& E\left(\mathrm{MS}_{0} \mid Y_{i,}^{\prime} R_{i}=0\right)=\beta_{0} Y_{i}^{\prime}+\delta_{0 u} \lambda_{0},
\end{aligned}
$$

where $\lambda_{1}$ and $\lambda_{0}$ are the Inverse Millis Ratio, $\lambda_{1}=\frac{\phi(\gamma x)}{\Phi(\gamma x)}$ and $\lambda_{0}=-\frac{\phi(\gamma x)}{1-\Phi(\gamma x)}$ and they have generated regressors from fertilizer probit estimation. Following Amare et al. 
[1] and Madalla and Nelson [31], the mean outcome variable because of technology adoption is estimated as:

$$
\begin{gathered}
E\left(\mathrm{MS}_{1} \mid Y_{i}^{\prime} R_{i}=1\right)-\left(\mathrm{MS}_{0} \mid Y_{i}^{\prime} R_{i}=1\right) \\
\quad=Y_{i}^{\prime}\left(\beta_{1}-\beta_{0}\right)+\delta_{1 u} \lambda_{1}-\delta_{0 u} \lambda_{0} .
\end{gathered}
$$

The second term on the left-hand side of Eq. (11) is the expected value of marketed surplus if the household had not adopted the technology during the production year.

The above framework can be also used to estimate the average treatment effect on the treated (ATT) and treatment effect on the untreated (ATU) by comparing the expected values of the outcome variable of adopters and non-adopters in actual and counterfactual scenarios. Following Carter and Milon [32], Di Falco et al. [33], I compute the ATT and ATU in the actual and counterfactual scenarios from the estimates of Endogenous Switching Regression models. This allows for computing the expected values in the real and hypothetical scenarios presented in Table 4. The four scenarios of expected outcome difference can be computed as follows:

Adopters with adoption (observed in the sample):

$$
E\left(B_{i 1} \mid R=1, Y\right)=\beta_{1} Y_{i 1}+\delta_{1 \varepsilon} \lambda_{i 1} .
$$

Non-adopters without adoption (observed in the sample):

$$
E\left(B_{i 2} \mid R=0, Y\right)=\beta_{2} Y_{i 2}+\delta_{2 \varepsilon} \lambda_{i 2} .
$$

Non-adopters had they decided to adopt (counterfactual)

$$
E\left(B_{i 1} \mid R=0, Y\right)=\beta_{2} Y_{i 2}+\delta_{2 \varepsilon} \lambda_{i 2} .
$$

Adopters had they decided not to adopt (counterfactual)

$$
E\left(B_{i 1} \mid R=1, B\right)=\beta_{1} Y_{i 1}+\delta_{1 \varepsilon} \lambda_{i 1} .
$$

Equations (11.1) and (11.2) represent the actual expectations of the outcome variable observed from the sample, while Eqs. (11.3) and (11.4) are the counterfactual expected outcomes. Following this conditional expectation, the expected marketed surplus difference can be computed. The expected change in non-adopters' marketed surplus, the effect of treatment on the treated can be computed as the difference between Eqs. (11.1) and (11.2). The intuition is that the expected change in the outcome variable for adopters given they have the same characteristics as non-adopters. The term $\lambda$ is the selection term that captures all potential effects of difference in the unobservable variables. Similarly, the expected change in non-adopters' marketed surplus, the effect of the treatment on the untreated is also computed as the difference between Eqs. (11.3) and (11.4). The economic interpretation is that the expected change in the non-adopters' expected outcome given non-adopters characteristics had similar characteristics as adopters. The term $\lambda$ adjusts the effect of treatment on the untreated for the effect of unobservable factors.

\section{Data and sampling frame}

The data used in this paper come from a cross-sectional data of 626 farm households surveyed in 2014-2015 production season from rural Tigrai, northern Ethiopia. All households in the sample are landholders and farming is the main source of livelihood (crop and livestock production). To get representative households, a two-stage sampling technique is applied as described by Hagos and Holden [34]. In the first stage, communities from five out of six zones of the study region namely: southern, southeastern, eastern, central and northern west were stratified based on variations in agricultural production potential, access to irrigation and market, population density, and agro-ecology diversification. ${ }^{1}$ In the second stage, households were randomly selected from the sampled communities for a detailed interview.

The survey comprises household composition and characteristics such as head's gender, age, literacy status, non-land resource endowments such as ox and non-ox livestock, and the number of active labor force. The gender distribution of households' head helps to address the sole responsible person on technology adoption and markets that making most farming decisions. The human productive element of household (active labor force) presents the capability of undertaking the laborious task, apply their effort to rapid adoption of modern farm input and exploit the market opportunities. The human capital element of households expressed in terms of literacy and farming experience proxy by young age of household head improved the awareness on the importance of adopting agricultural technologies and market participation. Education status of household heads is captured as a dummy variable by giving value one for those who are unable to read and write (illiterate) and give zero for those who can read and write.

Households' output market participation survey includes type and quantity of agricultural products (output of all crops and their by-products excluding livestock products), produced, consumed, sold and purchased along with selling and purchasing community-level median price.

In this study, smallholders' output market participation exhibits 'dichotomous', i.e., households with positive

\footnotetext{
1 The only zone, which is not included in this study was western zone, because smallholder farmers in the western zone are significantly small in number.
} 
Table 1 Variables' definition and their descriptive statistics Source: NUMB and MU household survey, 2014-2015

\begin{tabular}{|c|c|c|c|c|c|c|}
\hline Variable & Variables' definition & Obs & Mean & Std. dev. & Min & Max \\
\hline Fert_adop & Adoption of fertilizer (yes $=1,0$ otherwise) & 626 & 0.70 & 0.46 & 0 & 1 \\
\hline Frt_hac & Fertilizer use (kg/ha) & 626 & 94 & 188 & 0 & 1600 \\
\hline Gsale_parit & Output market participation (yes $=1,0$ otherwise) & 626 & 0.59 & 0.49 & 0 & 1 \\
\hline Mktsur & Marketed surplus of household (Birr) & 626 & 16,799 & 47,565 & $-86,570$ & 34,4166 \\
\hline psexF1 & Gender of the household head (female $=1$ ) & 626 & 0.28 & 0.45 & 0 & 1 \\
\hline page & Age of the household head (years) & 626 & 57.84 & 15.23 & 20 & 99 \\
\hline peduH & Educational status (illiterate = 1, 0 otherwise) & 626 & 0.910 & 0.011 & 0 & 1 \\
\hline Famsize & Family size of household (number) & 626 & 5.53 & 2.53 & 1 & 12 \\
\hline male_adult & The number of male adults & 626 & 1.93 & 1.46 & 0 & 8 \\
\hline female_adult & The number of female adults & 626 & 1.55 & 1.18 & 0 & 6 \\
\hline Oxen_qty & The number of oxen ownership & 626 & 1.08 & 1.08 & 0 & 8 \\
\hline TLU_Nox & The non-ox tropical livestock (TLU) & 626 & 3.57 & 3.73 & 0 & 26.5 \\
\hline Acceinfo & Access to information (yes $=1$ ) & 626 & 0.25 & 0.43 & 0 & 1 \\
\hline Ownland_ha & Household owns land size in hectare & 626 & 1.02 & 0.76 & 0.03 & 5.5 \\
\hline farmsize_ha & Household operated land size in hectare & 626 & 1.12 & 0.87 & 0.06 & 7.55 \\
\hline Acces_irrg & Access to irrigation (yes $=1$ ) & 626 & 0.30 & 0.46 & 0 & 1 \\
\hline distmkt_hr & Distance to nearby market (hour) & 626 & 1.28 & 0.95 & 0 & 4.5 \\
\hline distanceto t & Distance to plot (hour) & 626 & 0.50 & 0.40 & 0.08 & 4 \\
\hline distworda_h & Distance to district office (hour) & 626 & 2.81 & 1.51 & 0 & 12 \\
\hline Cropin_Aju & Total crop income (Birr/hh) & 626 & 18,428 & 55,222 & 30 & $1,111,911$ \\
\hline pcapcrcon u & Per capita crop consumption (Birr) & 623 & 785 & 1745 & 2.42 & 18964. \\
\hline SRF_3yrmean & Rainfall of previous 3 years to cropping season (mm) & 626 & 102.29 & 38.50 & 46.97 & 205.1 \\
\hline SstdevRF_3 n & Rainfall variability (std.dev) of previous 3 years to cropping season (mm) & 626 & 12.88 & 4.80 & 0.768 & 19.70 \\
\hline
\end{tabular}

marketed surplus treated as a net seller of food crops while a household with a negative marketed surplus considered as a net buyer of food crops. Therefore, the impact evaluation of fertilizer adoption on smallholders' commercialization is considered on the improvement of the net seller status of food crop, providing that the marketed surplus difference observed between the adopters and the non-adopters is attributed to adoption.

The survey also captured plot-level characteristics such as perceived soil quality or fertility; soil type, plot size, and area planted measured in $\mathrm{m}^{2}$ with the help of Global Position System (GPS) and converted into hectare. ${ }^{2}$ The household-plot surveys were supplemented by community-level data such as population density, access to all-weather roads, market places and rainfall data. Population density is measured by dividing the number of persons living in an area of square kilometer. A higher population leads to lower per capita land size and forced

\footnotetext{
${ }^{2}$ Framers have different plots with different biophysical characteristics, for example, a farmer may have a plot with low soil fertility (1), medium soil fertility (2), and higher soil fertility (3). I take the average plot soil fertility characteristics of a household by taking an index (multiplying plot soil fertility characteristics low, medium or higher by the number of plots belongs to group and divided by the total number of plots).
}

to apply land-use intensification using agricultural technologies to meet households' food security. Access to all-weather roads proxy by the one-way walking hours to reach the road that serves during rain and non-rain seasons.

Short distance to the road reduces the transaction cost of technology adoption and market participation. Rainfall data was captured in terms of average rainfall intensity and rainfall variability of the previous 3 years rainy season to the cropping period from daily satellite records at community level.

\section{Results and discussion}

Results of descriptive analysis

Table 1 presents the summary statistics of variables used in the analysis. The proportion of households who adopted inorganic fertilizer in the previous cropping season accounts $70 \%$ and the intensity of fertilizer used per hectare of land cultivated is about $94 \mathrm{~kg}$. About $60 \%$ of farm households have participated in the output market as a seller and buyer of food crops and the positive marketed surplus of average household accounts 16, 799 Birr per household. The gender and age distribution of household heads show that female-headed households are about $28 \%$, and the average age of household heads 
Table 2 Comparative assessment of key variables for fertilizer adopters and no adopters. Source: NMBU and MU household survey, 2014-2015

\begin{tabular}{|c|c|c|c|c|}
\hline Explanatory variables & Total (626) & Adopters $(N=441)$ & Non-adopters $(N=185)$ & Sig diff \\
\hline Gender of household head (female $=1$ ) & $0.283(0.018)$ & $0.234(0.201)$ & $0.397(0.015)$ & $* * *$ \\
\hline Age of head (years) & $57(0.609)$ & $58(0.675)$ & $55(1.274)$ & $* *$ \\
\hline Education level of head (illiterate $=1$ ) & $0.910(0.011)$ & $0.962(0.013)$ & $0.888(0.015)$ & $* * *$ \\
\hline Family size (number) & $5.52(0.100)$ & $6.00(0.110)$ & $4.38(0.192)$ & $* * *$ \\
\hline Adult male (number) & $1.93(0.058)$ & $2.18(0.067)$ & $1.346(0.100)$ & $* * *$ \\
\hline Adult female (number) & $1.544(0.047)$ & $1.69(0.055)$ & $1.204(0.086)$ & $* * *$ \\
\hline Own land (ha) & $1.024(0.030)$ & $0.990(0.036)$ & $1.103(0.053)$ & * \\
\hline Operational farm size (ha) & $1.122(0.034)$ & $1.08(0.038)$ & $1.207(0.074)$ & * \\
\hline Non-ox total livestock (TLU) & $3.56(0.149)$ & $3.94(0.172)$ & $2.674(0.281)$ & $* * *$ \\
\hline Oxen owned (number) & $1.08(0.043)$ & $1.202(0.047)$ & $0.790(0.086)$ & $* * *$ \\
\hline Per capita crop income (Birr) & $5400(579)$ & $4953(591)$ & $6139(1357)$ & ** \\
\hline Per capita consumption (Birr) & $2125(123)$ & $2155(156)$ & $1865(192)$ & \\
\hline Marketed surplus (Birr/hh) & $16,778(1904)$ & $16,814(2240)$ & $16,762(3591)$ & \\
\hline Household is net seller of food crop (yes $=1$ ) & $0.659(0.018)$ & $0.665(0.022)$ & $0.645(0.035)$ & \\
\hline Household is net buyer of food crop ( $1=$ yes) & $0.321(0.018)$ & $0.313(0.022)$ & $0.338(0.034)$ & \\
\hline Plot distance from homestead (hour) & $0.499(0.016)$ & $0.469(0.018)$ & $0.580(0.031)$ & $* * *$ \\
\hline Average plot quality ( $1=$ good) & $0.334(0.018)$ & $0.295(0.021)$ & $0.424(0.036)$ & $* * *$ \\
\hline Access to information ( $1=$ yes) & $0.246(0.017)$ & $0.270(0.021)$ & $0.188(0.028)$ & $* *$ \\
\hline Access to irrigation ( $1=$ yes $)$ & $0.299(0.018)$ & $03(0.021)$ & $0.295(0.033)$ & \\
\hline Household reside in high populated area ( $1=$ yes) & $0.56(0.019)$ & $0.561(0.023)$ & $0.559(0.036)$ & \\
\hline
\end{tabular}

$*^{* *}$, and ${ }^{* * *}$, significance at 10.5 and $1 \%$, respectively. Numbers in parenthesis are standard errors

is about 57 years. This implies that the majority of the household heads are male-dominated and on average, heads are still in the productive age range and expected to have good farming experience and land management.

Table 1 also reveals that the average family size for sampled households consists of five persons per household and more than $76 \%$ of households have above four family members. With regard to the educational status of household heads, Table 1 shows that about $60 \%$ of household heads are illiterate implying that they cannot read and write. This might be due to poor access to education in the rural part of the study region. About $30 \%$ of farm households have access to irrigation service and $70 \%$ of the irrigator households have participated in the output market as a crop seller. This may indicate that irrigation enhances the probability of smallholders' market participation through producing cash crops or high-value crops. The proportion of households' access to information proxy by ownership of communication devices such as mobile phones, television, and radio accounts for $25 \%$.

Landholding size of farm households is one hectare, which is equivalent to the country's average (Gebremedhin et al. [13]) and about 38\% of farm households owned less than 0.75 hectare. Operational land size is slightly higher than the owned landholding. The extra cultivable land size over the landholding might come from renting in (the sharecropping or fixed rent contract arrangement) or temporarily transferred into the sampled households. On average, farm households travel half an hour to reach their plots for farming activities and about 1.28 hour to reach nearby market place. Previously 3 years rainy season (June to September) rainfall and rainfall variability proxy by standard deviation accounts $102.29 \mathrm{~mm}$ and $12.88 \mathrm{~mm}$, respectively.

Table 2 presents the comparative assessment of key variables for fertilizer adopter and non-adopter households. Results show that fertilizer adopter households are distinct from fertilizer non-adopter households in terms of demographics and household endowments. On average, the family size of fertilizer adopter households is significantly higher than non-adopters, indicating the food security implication of the technology adoption that enabled them to produce sufficient food crops to feed more mouths. The gender distribution of technology adopter categories shows that male-headed households adopt fertilizer more than female-headed households and the difference is statistically significant at the $1 \%$ level. This might be due to farming particularly, plowing with oxen is mainly associated with male's work in the study region and the application of fertilizer may demand extra male labor. 
Fertilizer adopter households have a large number of oxen and non-oxen livestock units (in TLU), male and female adults. This suggests that in the imperfect input and output markets, endowments play an important role in neutralizing the risk effect of technology adoption. Hence, wealthier households are more likely to adopt inorganic fertilizer compared to poor households. Table 2 also depicts that on average, fertilizer adopter households have poor land quality. That is expected. Since fertilizer is used first to enhance soil fertility and then improved plot-level crop productivity. Thus, farmers with poor land quality are more likely to adopt fertilizer compared to farmers owned relatively with good land quality. The result is consistent with the study of Gurara and Larson [35], which revealed an inverse relationship between the extent of inorganic fertilizer use and good plot's quality. Fertilizer adopter households have owned and operated slightly lower land size than fertilizer non-adopters and the difference is statistically significant at the $1 \%$ level. This shows a strong correlation between land-use intensification and small landholding size.

As far as households' access to information is concerned, fertilizer adopters are accessible to information better than non-adopters and the difference is statistically significant at the $1 \%$ level. The intuition is that households who have access to information are expected to reduce fixed transaction costs and are in a better place to get updated information pertaining to the technology and market opportunities from extension agents, model farmers, and technology suppliers or distributors. There was a scant variation between the adopters' categories, as far as per capita consumption is concerned while there is a statistical and significant difference in per capita crop income between adopters and non-adopters. On average, about $66 \%$ of farm households were net sellers of food crops (with positive marketed surplus), while 32\% of farm households were net buyers of food crops (with negative marketed surplus). The remaining two percent of sampled households were autarky, with zero marketed surplus.

\section{Estimation results}

\section{Determinants of technology adoption}

The estimated results for double-hurdle model using craggit command (hurdle- 1 for the probability of fertilizer adoption and hurdle- 2 for the extent of fertilizer adoption) are presented in Table 3. I test whether smallholder farmers make demand decisions (adoption and extent of adoption of technologies) simultaneously versus sequentially. This was done by examining how well the tobit model fit to my data compared to the DH model. I estimate the two models separately with variables presented in Table 3. Tobit results are presented in Annex
Table 7 for comparison purposes. I observe comparable results are robust to the model specifications. But, the likelihood ratio test shows that the censored tobit model nests in the two-stage double-hurdle model and the test rejects the censored tobit model in favor of the double hurdle $\left(\chi_{(32)}^{2}\right)=121.1$, prob $\left.=0.0000\right)$. Moreover, the Akaike Information Criterion (AIC $=2542)$ and Bayesian Information Criterion $(\mathrm{BIC}=2688)$ estimates also substantiated the same that double-hurdle model to be better fit the data.

Henceforth, I base my discussion on the results from the double-hurdle model and state that the extent of adoption of the technology needs to be estimated conditional on the likelihood of adoption decision. This proposes that farmers in northern Ethiopia make technology demand decisions sequentially that first deciding to adopt or not and then deciding how much to adopt. Furthermore, the Wald test for instance, $\left(\chi^{2}\left(\mathrm{chi}^{2}\right)=138.08\right.$, $P=0.0000)$ in the double-hurdle model is significant at the $1 \%$ level. This indicates that the subset of coefficients of the double-hurdle model is jointly significant and that the explanatory power of the variables comprised in the model is satisfactory. Besides, the model allows different explaining power of a variable in the hurdle 1 and hurdle 2. This suggests that variable with a significant effect in hurdle 1 may not necessarily significant in hurdle 2 also. This confirms my assumption that the probability and degree of adoption are performed in a separate process.

I present the result of double-hurdle models with and without the endogenous variables. This is done to check the robustness of the model estimation and exclusion of endogenous variables do not affect model results. Hence, I base results interpretation based on the strict exogenous controls. Three variables include family size, number of male and female adults were affect positively and significantly the probability of fertilizer adoption. Given the importance of human labor in land investment and management, the marginal effects show that, on average, for an increase of family member and adult labor force (male and female adult) by one, the probability of fertilizer adoption increased by about $43.5 \%, 8.3 \%$ and $13.1 \%$, respectively. On the contrary, the probability of fertilizer adoption correlated negatively and significantly, at the $1 \%$ level with female-headed households. This indicates that farming particularly plowing with oxen is a typical male's task in the study area and females are less likely to participate in technology adoption. The marginal effect shows that the probability of fertilizer adoption decreased by $38.2 \%$ when plots are administered by female-headed households. The finding is consistent with the study of Gebregziabher and Holden [36] and Yu et al. [37] that female-headed households are less likely to adopt inorganic fertilizer. 
Table 3 Factors affecting adoption of inorganic fertilizer (craggit models). Source: NUMB and MU household survey, 2014-2015

\begin{tabular}{|c|c|c|c|c|}
\hline \multirow[t]{2}{*}{ Explanatory variables } & \multicolumn{2}{|c|}{ Without endogenous variables } & \multicolumn{2}{|c|}{ With endogenous variables } \\
\hline & $\begin{array}{l}\text { Hurdle 1: probability } \\
\text { of adoption }\end{array}$ & $\begin{array}{l}\text { Hurdle 2: log } \\
\text { of fertilizer used (kg/ } \\
\text { ha) }\end{array}$ & $\begin{array}{l}\text { Hurdle 1: probability } \\
\text { of adoption }\end{array}$ & $\begin{array}{l}\text { Hurdle 2: log } \\
\text { of fertilizer used } \\
\text { (kg/ha) }\end{array}$ \\
\hline Head's gender (female $=1$ ) & $-0.382^{* * *}(0.142)$ & $-0.002(0.081)$ & $-0.341^{* *}(0.145)$ & $0.016(0.081)$ \\
\hline Head's age (year) & $0.004(0.004)$ & $0.002(0.002)$ & $0.004(0.004)$ & $0.002(0.002)$ \\
\hline Head's education (illiterate $=1$ ) & $-0.435^{* * *}(0.130)$ & $-0.110^{*}(0.065)$ & $-0.406^{* * *}(0.131)$ & $-0.112^{*}(0.065)$ \\
\hline Family size (number) & $0.083^{* *}(0.040)$ & $0.065^{* *}(0.021)$ & $0.062(0.041)$ & $0.057^{* * *}(0.021)$ \\
\hline Male adult (number) & $0.131^{* *}(0.063)$ & $-0.019(0.031)$ & $0.134^{* *}(0.063)$ & $-0.022(0.030)$ \\
\hline Female adult (number) & $0.125^{* *}(0.066)$ & $0.011(0.034)$ & $0.119^{*}(0.067)$ & $0.010(0.034)$ \\
\hline Own land (ha) & $-0.115(0.084)$ & $0.087^{*}(0.047)$ & $-0.106(0.085)$ & $0.092^{* *}(0.047)$ \\
\hline Distance to farmers training center (hour) & $-0.087(0.077)$ & $-0.070(0.047)$ & $-0.079(0.078)$ & $-0.067(0.046)$ \\
\hline Distance to district office (hour) & $0.054(0.045)$ & $-0.018(0.027)$ & $0.059(0.045)$ & $-0.025(0.027)$ \\
\hline Plot distance (hour) & $-0.427^{* * *}(0.154)$ & $-0.121(0.088)$ & $-0.430^{* * *}(0.156)$ & $-0.118(0.087)$ \\
\hline Mean rainfall rainy season of past 3 years $(\mathrm{mm})$ & $-0.016^{* * *}(0.006)$ & $0.008^{* *}(0.004)$ & $-0.015^{* *}(0.006)$ & $0.009^{* *}(0.004)$ \\
\hline $\begin{array}{l}\text { Rainfall variability (std dev) of rainy season of past } \\
3 \text { years }(\mathrm{mm})\end{array}$ & $0.015(0.031)$ & $-0.020(0.013)$ & $0.013(0.031)$ & $-0.024^{*}(0.013)$ \\
\hline Soil quality (medium = 1) & $-0.155(0.154)$ & $0.061(0.083)$ & $-0.135(0.155)$ & $0.064(0.082)$ \\
\hline Soil quality (good =1) & $0.047(0.158)$ & $-0.011(0.085)$ & $0.089(0.160)$ & $0.033(0.086)$ \\
\hline Crop type (leguminous $=1$ ) & $-0.059(0.143)$ & $0.097(0.074)$ & $-0.106(0.144)$ & $0.068(0.074)$ \\
\hline Crop type (vegetables $=1$ ) & $-0.692^{* * *}(0.215)$ & $-0.097(0.137)$ & $-0.728^{* * *}(0.217)$ & $-0.115(0.137)$ \\
\hline Soil type (Walka, Vertisol=1) & $-0.455^{* *}(0.231)$ & $0.155(0.115)$ & $-0.431^{* *}(0.235)$ & $0.177(0.115)$ \\
\hline Soil type (Hutsa, Leptosol=1) & $-0.202(0.246)$ & $0.179(0.115)$ & $-0.183(0.249)$ & $0.195^{*}(0.115)$ \\
\hline Soil type (Mekayhi, Luvisol=1) & $-0.690^{* * *}(0.254)$ & $0.118(0.127)$ & $-0.659^{* *}(0.258)$ & $0.130(0.126)$ \\
\hline Soil depth $($ deep $=1)$ & $0.102(0.152)$ & $0.208^{* * *}(0.076)$ & $0.134(0.154)$ & $0.222^{* * *}(0.077)$ \\
\hline Soil depth $($ Steep $=1)$ & $-0.018(0.184)$ & $0.117(0.101)$ & $-0.036(0.187)$ & $0.099(0.100)$ \\
\hline Oxen owned (number) & & & $0.109 *(0.061)$ & $0.097^{* * *}(0.033)$ \\
\hline Access to irrigation (yes $=1$ ) & & & $-0.019(0.137)$ & $0.095(0.073)$ \\
\hline Access to information (yes $=1$ ) & & & $0.232(0.149)$ & $-0.039(0.073)$ \\
\hline District fixed effect & Yes & Yes & Yes & Yes \\
\hline _cons & $1.927^{* *}(0.839)$ & $3.274(0.456)$ & $1.693^{* *}(0.849)$ & $3.132^{* * *}(0.453)$ \\
\hline sigma cons & & $0.655^{* * *}(0.022)$ & & $0.647^{* * *}(0.022)$ \\
\hline AIC & 1597.589 & & 1592.517 & \\
\hline $\mathrm{BIC}$ & 1886.147 & & 1907.711 & \\
\hline Wald Chi ${ }^{2}$ & 135.12 & & 138.08 & \\
\hline Prob $>\mathrm{Chi}^{2}$ & 0.0000 & & 0.0000 & \\
\hline Log-likelihood ratio & -731.73 & & -725.25 & \\
\hline Total observation & 626 & 440 & 626 & 440 \\
\hline
\end{tabular}

***, and ${ }^{* * *}$ are significant at 1,5 and $10 \%$ significance levels, respectively. Numbers in parenthesis are robust 3 standard errors clustered at household

The probability of fertilizer adoption correlates negatively and significantly with plot distance. The marginal effect shows that as plot distance proxy by walking time from homestead increased by an hour, the probability of fertilizer adoption declined by about $42.7 \%$. Lower probability of fertilizer adoption has also associated with cash crop (vegetable $=1$ ) grower households compared to cereal crop growers. This may be due to areas used for cash crops were covered with the smallest portion of the total cultivated area of the study region. I further assess the consistency and robustness of these findings by inspecting the results from hurdle 2 model that focuses on the extent of fertilizer adoption in the next section.

Results from the second hurdle show that family size, owned landholding, rainfall of previous 3 years rainy season and households having plots with deep soil depth influence positively and significantly the extent of fertilizer use. I observe that head's education (illiterate $=1$ ) 
Table 4 Factors affecting plot-level productivity (log value of crop produced per hectare). Source: NMBU and MU household survey, 2014-2015

\begin{tabular}{|c|c|c|c|}
\hline Variables & Model 1 & Model 2 & Model 3 \\
\hline Instrument: distance to plot (hour) & $-0.776^{* * *}(0.266)$ & $-0.263(0.173)$ & \\
\hline Log of fertilizer used (kg/ha) & & $0.228^{* * *}(0.037)$ & $0.646^{* * *}(0.093)$ \\
\hline Residual from first stage & & & $-0.451^{* * *}(0.092)$ \\
\hline Head's gender (female $=1$ ) & $-0.597^{* *}(0.244)$ & $-0.026(0.152)$ & $0.193(0.173)$ \\
\hline Head's age (years) & $0.009(0.007)$ & $-0.009^{* *}(0.005)$ & $-0.013^{* * *}(0.005)$ \\
\hline Head's education (illiterate $=1$ ) & $-0.689^{* * *}(0.207)$ & $0.146(0.140)$ & $0.471^{* * *}(0.152)$ \\
\hline Family size (number) & $0.169^{* *}(0.067)$ & $0.126^{* * *}(0.044$ & $-0.086(0.055)$ \\
\hline Male adult (number) & $0.189^{* *}(0.098)$ & $-0.046(0.065)$ & $-0.106(0.058)$ \\
\hline Female adult (number) & $0.202^{* *}(0.107)$ & $-0.0698(0.071)$ & $0.193^{* *}(0.173)$ \\
\hline Access to irrigation (yes $=1$ ) & & $0.502^{* * *}(0.149)$ & $0.451^{* * *}(0.128)$ \\
\hline Rainfall of production season & & $0.033(0.021)$ & $0.024(0.033)$ \\
\hline Constant & $3.601^{* * *}(1.390)$ & $6.641^{* * *}(1.38)$ & $6.698^{* * *}(2.177)$ \\
\hline Crop fixed effect & Yes & Yes & Yes \\
\hline Plot characteristics & Yes & Yes & Yes \\
\hline District fixed effect & Yes & Yes & Yes \\
\hline$R^{2}$ & & 0.2249 & 0.2404 \\
\hline Left censored observation & 186 & & \\
\hline Uncensored observation & 440 & & \\
\hline Prob $>c h i^{2}$ & 0.000 & 0.0000 & 0.0000 \\
\hline Total observation & 626 & 626 & 626 \\
\hline
\end{tabular}

***, *****efers at 1,5 and $10 \%$ level of significance. Numbers in parenthesis are standard errors bootstrapping with 4400 replications

has a negative and statistically significant effect on the extent of fertilizer adoption at the $10 \%$ level. The marginal effect shows that for illiterate headed households, the extent of fertilizer adoption decreased by $11 \%$, suggests that farming in the study area is small scale and acquiring higher-level education is not much important to manage plots and less likely to adopt the technology adoption. My result is consistent with the study of Asfaw and Admassie [38] Gebregziabher and Holden [36]. Risk variables proxy by previous 3 years rainy season rainfall affects adoption intensity of fertilizer in the latter period. This implies that households reside in a community with relatively higher rainfall from the mean value of previously 3 -year rainy season leads to use high amount of inorganic fertilizer in the latter period compared to households live in areas with low amount of rainfall. Keeping others constant, for an increase of rainfall in the previous 3 years rainy season by $10 \mathrm{~mm}$ from the mean, intensity of fertilizer used increased by about $8 \%$. This result is consistent with the study of Holden et al. [39] and Alem et al. [40]; availability of better rainfall encourages to use more amount of inorganic fertilizer per hectare of land in semi-arid of Ethiopia.

\section{Impact of fertilizer adoption on crop productivity}

Before I see the impact of fertilizer adoption on smallholders' commercialization, first I test whether the intensity of fertilizer use influences plot-level productivity. The argument is that fertilizer adoption improves plot level productivity, achieves household-level food security, and perhaps generates surplus products and enhanced smallholders' output market participation as a crop seller. Impact results of fertilizer use on plot-level productivity are presented on Table 4 and include three different specifications. Model 1 is the first stage fertilizer use estimation results, which is a function of the instrumental variable (distance to plot) along with other control variables. Model 2 excluded the instrument but included the strict exogenous control variables of the second stage. Model 3 includes the residual generated from first stage tobit model along with the endogenous regressor.

As shown from Table 4, the instrumental variable (distance to plot) is significant with a negative sign in the first stage tobit model at the $1 \%$ level (Model 1 ), while insignificant in the standard test level in the second stage model (Model 2). The inclusion of the residual tests and controls for the endogeneity of fertilizer adoption. Standard errors are estimated using the bootstrapping method to account for the two-stage estimation in this control function procedure. The coefficient of the residual is 
Table 5 Determinants of marketed surplus with and without fertilizer adoption (log of marketed surplus): an endogenous switching regression model. Source: NMBU and MU household survey, 2014-2015

\begin{tabular}{lll}
\hline Variables & Adopters & Non-adopters \\
\hline Head's gender (female $=1)$ & $-0.060(0.302)$ & $1.259^{* * *}(0.421)$ \\
Head's age (years) & $-0.026^{* * *}(0.008)$ & $-0.013(0.010)$ \\
Head's education (illiterate $=1)$ & $0.108(0.257)$ & $-0.080(0.493)$ \\
Family size (number) & $-0.166^{* *}(0.081)$ & $0.206(0.152)$ \\
Male adult (number) & $-0.106(0.120)$ & $-0.262(0.227)$ \\
Female adult (number) & $-0.109(0.129)$ & $-0.087(0.216)$ \\
Oxen owned (number) & $0.498^{* * *}(0.167)$ & $0.515^{* *}(0.241)$ \\
Non-ox Tropical Livestock unit (TLU) & $-0.055(0.046)$ & $0.107^{*}(0.0619)$ \\
Distance to district office (hour) & $-0.291(0.256)$ & $0.526(0.419)$ \\
Distance to nearby market (hour) & $0.094(0.141)$ & $-0.21(0.181)$ \\
Second tercile land owned (ha) & $0.949^{* * *}(0.313)$ & $1.213^{* *}(0.5809$ \\
Third tercile land owned (ha) & $1.537^{* * *}(0.312)$ & $1.188^{*}(0.6219)$ \\
Access to irrigation (yes $=1)$ & $1.064^{* * *}(0.264)$ & $-0.235(0.425)$ \\
Constant & $11.27^{* * *}(0.685)$ & $6.670^{* * *}(1.199)$ \\
Inverse Millis Ratio one $\left(\lambda_{1}\right)$ & $-1.521(0.765)$ & $-0.186(0.603)$ \\
Inverse Millis Ratio one $\left(\lambda_{0}\right)$ & & $9.775(0.980)$ \\
Predicted marketed surplus & $10.326(1.059)$ & \\
Significant difference of predicted marketed surplus of adaptors-non-adopters & $0.550^{* * *}(0.094)$ & \\
$\quad$ observation & 440 & 186 \\
Number of observations & & \\
\hline
\end{tabular}

First trices are used a base for land ownership category

***, ** level of significance at 1 and 5\%, respectively

significant at the $1 \%$ level (Model 3), which implies adoption of inorganic fertilizer is potentially endogenous as expected and, therefore, the control function approach works nicely.

Results indicate that the coefficient of fertilizer use on the plot-level productivity is positive and significant (Model 3). On average, when the amount of fertilizer used increased by $10 \%$ from the mean, plot-level productivity increased by about $6.5 \%$ at the $1 \%$ level. This result shows that fertilizer adopters actually make much difference in crop productivity and perhaps market participation as a crop seller among the farm households and support the prior expectation. After ascertaining a positive impact of the fertilizer use on plot-level productivity, I then proceed to estimate the impact of fertilizer adoption on smallholders' commercialization.

\section{Impact of fertilizer adoption on smallholders' commercialization}

As discussed in the theory and the identification strategy section, I intend to see how fertilizer adoption affects smallholders' commercialization. When I look at the status of households regarding output market participation, I have three types of participants. The first type comprises households who had a positive marketed surplus
(407 households) while the second type of participants are those who have a negative marketed surplus (213 households), the remaining households are those who have zero marketed surplus (6 households). In this study, therefore, I do the impact identification of fertilizer adoption considering the first two categories of output market participants.

The full maximum likelihood estimates of the endogenous switching regression model are reported in Table 5. A broad set of control variables including household demographics, household endowments, and communitylevel factors were included in the estimation. I sort out land endowment into three groups (terciles) to assess how market participation is sensitive to size of landholding. The first tercile include households with landholding between 0.03 and 0.625 hectare. Households with landholding fall in the second tercile between 0.656 and 1.09 hectare and household with landholding falls in the third tercile is between 1.125 and 5.5 hectare. Since the outcome variable is expressed in log form, for a unit change of continuous variable and change from zero to one for dummy variables, results are interpreted in percentage. Results depicted factors affecting marketed surplus for adopters and non-adopters. 
Table 6 Summary of predicted values for marketed surplus for fertilizer adopters and non-adopters. Source: NMBU and MU household survey, 2014-2015

\begin{tabular}{lc}
\hline Types of users & Marketed surplus (\%) \\
\hline Predicted mean adopters $(N=440)$ & $12.75(0.069)$ \\
Predicted mean had they not been adopted & $11.6(0.124)$ \\
Predicted mean difference-test & $1.15^{* * *}(0.133)$ \\
Predicted mean non-adopters $(N=186)$ & $9.4(0.051)$ \\
Predicted mean had they been adopted & $10.5(0.077)$ \\
Predicted mean difference-test & $1.1^{* * *}(0.094)$ \\
\hline
\end{tabular}

Results are expressed in percentage form. Absolute value of $t$-statistic in parenthesis

***Refers significantly at the $1 \%$ level

The household head's age was associated negatively and significantly with marketed surplus of fertilizer adopter households. This may indicate that elder headed households were perhaps correlated with distrust the use of new technology and less likely to produce surplus products to the market for sale. Another possible justification could be, elderly headed households may lack the necessary human capital to apply the new technology and less likely to improve productivity beyond home consumption, and declined to participate in the output market as net seller of food crops. Households' resource endowments have a significant effect with a positive sign on marketed surplus for fertilizer adopters. For instance, for an extra unit of an ox increased the marketed surplus of fertilizer adopters by about $49.8 \%$ at the $1 \%$ level. Households with higher number of family sizes are associated with lower level of commercialization. The possible reason may be more of crop income is used for home consumption and the extent of surplus product could be marginally small. Households with landholding fall in the second and third terciles are associated with a positive marketed surplus of fertilizer adopter households at the $1 \%$ level. The result is quite remarkable that land wealthier households were more likely to adopt the new technology, improved plot-level productivity and potential generating surplus product for sale. The predicted mean marketed surplus depicts statistically significant differences between adopters and nonadopter households (see Table 5).

Following the results from the endogenous switching regression model, I compute the predicted value of marketed surplus for the adopter and non-adopter households. Since the switching regression model estimates the marketed surplus separately for the adopter and nonadopter households, it becomes crucial to examine the predicted difference of marketed surplus among adopters if they had not adopted and among the non-adopters if they had been adopted. Overall, the mean prediction estimates show that fertilizer adoption has a positive and significant effect on smallholders' commercialization (Table 6). This is shown by the difference in a positive marketed surplus of adopter households by about $1.2 \%$ higher than if they had not been adopting the technology. On the other hand, for non-adopter households, the mean positive marketed surplus would have been increased by about $1.1 \%$ had they been adopted with significant results.

\section{Overall discussion}

Considering input and output markets imperfections in developing countries, promoting adoption of agricultural technologies among farm households is one option of meeting food security and reducing the burden of welfare maximization. This may be also an important way to shift from subsistence to market-oriented agriculture, which the government of Ethiopia aims for. Most rural inhabitants of the country depend on small-scale agriculture for their livelihood. Moreover, over time decreasing per capita landholding due to higher population growth (the second most populated country in Africa), farm households seek additional sources of income besides agriculture. Although the concept of rural transformation is comprehensive and complex, that describes various simultaneous and intertwining dynamics, in this study, I attempt to narrate reducing farmers' reliance on subsistence agricultural system and shifts towards market-oriented production system. This could more prominent through scaling up production for market via the application of modern agricultural technologies. Better market participation can contribute significantly to wealth creation and supports the development of agro-value chains, and facilitates the shifts of informal economy into the formal economic sector. Technology adoption process has been increased since the Green revolution in 1964 and switch smallholder farmers their land from cultivating the conventionally way to genetically improved wheat and significantly improved yields more than tripled from 119.7 to $454.7 \mathrm{~kg} / \mathrm{hac}$. This enhancement was fundamentally supported by adequate supply of chemical fertilizer [41].

Previous researches have documented that adoption of agricultural technologies such as inorganic fertilizer are active in Ethiopia and enhanced the income and welfare of smallholders [42, 43]. One could therefore also hope that this would facilitate rural transformation [13, 17, 44]. However, due to input and out market imperfection, limited resource endowments and constrained access to the technology and information, the finding of this study demonstrates that the rate of adoption and extent of adoption of inorganic fertilizer per hectare of area planted are relatively low.

It is noteworthy that adoption of agricultural technologies plays such an important role in food security, climate change, and market integration as also in many countries 
where per capita land is limited and prevalent of high population growth. For instance, using the 2008-2009 survey data, adoption of improved maize varying from 65\% in Malawi Bezu et al. [45] to 43\% in Tanzania Amare et al. [1] where smallholder farmers were the sole operator. They also found that adoption of improved maize enhanced the food security and market participation of smallholders. In Uganda, Amare and Shiferaw [46] using national representative sample estimated that $8 \%$ of arable land was cultivated with improved seed in 2009-2010 and increased to 38\% in 2011-2012. Katangese et al. [47] also estimated that $29 \%$ of farm households were adopters of improved maize_legume intercropping in 2006 and its adoption rate has been reached nearly 2.4 times (70\%) in 2015 in Malawi. The importance of inorganic fertilizer on the adoption of the above-mentioned agricultural technologies is crucial. This indicates that inorganic fertilizer is truly complementary input to other agricultural practices in a semi-arid economy.

Therefore, establishment of efficient distributional centers via addressing the agro-ecology feature and better functioning of credit, infrastructure and agricultural extension become the key solution to the supply and demand sides of the technology. One can think a similar approach to improve technology adoption among smallholders is necessary to create food sufficiency, environmentally friendly farming practice and market integration in the semi-arid of Ethiopia.

\section{Conclusions}

This paper used a cross-sectional data of 626 smallholder farmers surveyed during 2014-2015 cropping season in rural Tigrai, northern Ethiopia. The specific objective of the paper was to analyze adoption determinants of inorganic fertilizer and its subsequent impact on smallholders' commercialization through productivity gain. Adoption determinants were estimated using doublehurdle models, plot-level productivity was estimated using OLS with a control function approach to fix the problem of endogeneity associated with fertilizer adoption. While impact of fertilizer adoption on marketed surplus was estimated using an endogenous switching regression model to account for the unobservable heterogeneity effect. The results from the double-hurdle model showed that family size, male and female adult labor force have a positive and significant effect on fertilizer adoption. While, female-headed households, illiterate headed households, and plot distance have a negative and significant effect on fertilizer adoption.

The simple linear regression model results depict that adoption of fertilizer measured in a $\log$ of $\mathrm{kg} / \mathrm{ha}$ of land has a strong and positive impact on plot-level productivity. The endogenous switching regression result revealed a strong and positive impact of fertilizer adoption on marketed surplus, suggested that the importance of controlling the unobserved heterogeneity effect in estimating the impact. In general, results verified the importance of technology adoption in improving productivity and translate into a higher marketed surplus.

The challenges and opportunities of rural transformation derived from smallholders' market participation depend on many sectors inside and outside of agriculture. To address effectively the process of shifting from subsistent to market base production system, a higher level of policy coherence between the desired overall growth pathway and agriculture, food security, market participation, and nutrition policies will be required. Special attention should be paid to link sectors like basic services (market, extension, infrastructure, etc.) with economic opportunities within and outside agriculture. Moreover, there should be due attention to rural development and integrated with output market that further improved food security, eliminate poverty and hunger of the rural society. Promoting agricultural technologies among smallholders is considered as one strategy of achieving the above goals.

\section{Abbreviations}

A: Adopters; NA: Non-adopters; ATT: Average treatment for the treated; ATU: Average treatment for untreated; DH: Double Hurdle; GPS: Global Position System; IV: Instrumental variable; Km: Kilometers; OLS: Ordinary least square; $\mathrm{MS}_{1}$ : Marketed surplus for adopters; $\mathrm{MS}_{0}$ : Marketed surplus for non-adopters.

\section{Acknowledgements \\ I am grateful to The Relief Society of Tigrai for providing satellite reading rainfall data.}

\section{Authors' contributions}

MG initiated the research work, data collected, wrote the proposal and all the follow-up tasks (data entry, cleaning, analysis and produce the manuscript). The author read and approved the final manuscript.

\section{Funding}

Data collection has been funded by the research funded by NORAD through the NOMA and NORHED programs, especially the "Climate-Smart Natural Resource Management and Policy" (CLISNARP) collaborative research and capacity-building program between the School of Economics and Business at Norwegian University of Life Sciences, Mekelle University, Ethiopia.

\section{Availability of data and materials}

The author attaches the data set used for the analysis along with this manuscript in STATA 13 format.

\section{Ethics approval and consent to participate}

Not applicable.

\section{Consent for publication}

Not applicable.

\section{Competing interests}

The author declares that he has no competing interests.

\section{Annex}

See Tables 7, 8. 
Table 7 Variables of the models and their hypothesized relationships on technology adoption, plot-level crop productivity and smallholders' commercialization. Source: NUMB and MU household survey, 2014-2015

\begin{tabular}{|c|c|c|c|c|c|}
\hline \multirow[t]{2}{*}{ Variable } & \multirow[t]{2}{*}{ Variables' description } & \multirow[t]{2}{*}{ Unit } & \multicolumn{3}{|c|}{ Prior expectation on } \\
\hline & & & $\begin{array}{l}\text { Fertilizer } \\
\text { adoption }\end{array}$ & Productivity & $\begin{array}{l}\text { Marketed } \\
\text { surplus }\end{array}$ \\
\hline Fert_adop & Adoption of fertilizer (yes $=1,0$ otherwise) & Dummy & & + & + \\
\hline psexF1 & Gender of the household head (female $=1$ ) & Dummy & - & - & - \\
\hline page & Age of the household head & Years & \pm & \pm & \pm \\
\hline peduH & Educational status (illiterate $=1,0=$ otherwise) & Dummy & \pm & \pm & \pm \\
\hline Famsize & Family size of household & Number & + & + & \pm \\
\hline male_adult & Male adults & Number & + & + & \pm \\
\hline female_adult & Female adults & Number & + & + & \pm \\
\hline Oxen_qty & Oxen ownership & Number & + & + & + \\
\hline TLU_Nox & Non-ox Tropical Livestock & TLU & + & + & + \\
\hline Acceinfo & Access to information (yes $=1$ ) & Dummy & + & + & + \\
\hline Ownland_ha & Household owns land size & Hectare & \pm & \pm & + \\
\hline Acces_irrg & Access to irrigation (yes $=1$ ) & Dummy & + & + & + \\
\hline distmkt_hr & Distance to nearby market & Hour & - & - & - \\
\hline distanceto t & Distance to plot & Hour & - & - & - \\
\hline SRF_3yrmean & Rainfall of previous 3 years to cropping season & Millimeter & + & & \\
\hline SstdevRF_3 n & Rainfall std. dev of previous 3 years to cropping season & Millimeter & - & & \\
\hline RFcupro & Rainfall of cropping season & Millimeter & + & + & + \\
\hline
\end{tabular}

Table 8 Factors affecting fertilizer adoption (log kg/ha) (tobit model). Source: NMBU and MU household survey 2014-2015

\begin{tabular}{ll}
\hline Variables & \\
\hline Head's gender & $-0.674^{* * *}(0.244)$ \\
Head's age & $0.009(0.007)$ \\
Head's education & $-0.739^{* * *}(0.209)$ \\
Family size & $0.217^{* * *}(0.066)$ \\
Male adult & $0.188^{* *}(0.099)$ \\
Female adult & $0.218^{* *}(0.108)$ \\
Ownland_ha & $-0.125(0.148)$ \\
Distance to farmers'training center & $-0.247^{*}(0.137)$ \\
Distance to district office & $0.090(0.078)$ \\
Plot distance & $-0.784^{* * *}(0.268)$ \\
Previous 3 years rainy season rainfall & $-0.026^{* *}(0.011)$ \\
Previous 3 years rainy season rainfall variability (std. & $0.011(0.044)$ \\
deviation) & \\
Plot characteristics & Yes \\
District fixed effect & Yes \\
Chi' & 191.33 \\
Log-likelihood & -1177.61 \\
Prob > chi ${ }^{2}$ & 0.0000 \\
Uncensored observation & 440 \\
Censored observation & 186 \\
Total observation & 626 \\
\hline
\end{tabular}

***,***, refer significant level at 1,5 and $10 \%$, respectively. Numbers in parenthesis are robust standard 5 errors cluster at household
Received: 11 November 2019 Accepted: 17 April 2020

Published online: 12 June 2020

\section{References}

1. Amare M, Asfaw S, Shiferaw B. Welfare impacts of maize-pigeon pea intensification in Tanzania. Agric Econ. 2012;43(1):27-43. https://doi.org/1 0.1111/j.1574-0862.2011.00563.x.

2. Godfray HC, Beddington JR, Crute IR, Haddad L, Lawrence D, Muir JF, Pretty J, Robinson S, Thomas SM, Toulmin C. Food security: the challenge of feeding 9 billion people. Science. 2010;327(5967):812-8.

3. Godfray HC, Garnett T. Food security and sustainable intensification. Phil Trans R Soc B Biol Sci. 2014;369(1639):20120273.

4. Asfaw S, Shiferaw B, Simtowe F, Lipper L. Impact of modern agricultural technologies on smallholder welfare: evidence from Tanzania and Ethiopia. Food Policy. 2012;37(3):283-95. https://doi.org/10.1016/j.foodp ol.2012.02.013.

5. Barrett CB, Bachke ME, Bellemare MF, Michelson HC, Narayanan S, Walker TF. Smallholder participation in agricultural value chains: comparative evidence from three continents. 2010. https://doi.org/10.2139/ssrn.17339 42.

6. Barrett CB. Smallholder market participation: concepts and evidence from eastern and southern Africa. Food Policy. 2008;33(4):299-317. https //doi.org/10.1016/j.foodpol.2007.10.005

7. Govereh J, Jayne T, Nyoro J. Smallholder commercialization, interlinked markets and food crop productivity: cross-country evidence in eastern and southern Africa. Michigan State University. Dept Agric Econ. 1999; 39. http://doi.10.1.1.151.5366\&rep=rep1\&type=pdf.

8. Von Braun J. Agricultural commercialization: impacts on income and nutrition and implications for policy. Food Policy. 1995:20(3):187-202. https://doi.org/10.1016/0306-9192(95)00013-5.

9. Von Braun J. 1. Small-scale farmers in liberalized trade environment. Small-scale. 2004; 21

10. Alemaw AT. Impact of improved maize varieties adoption on smallholder farmers' marketed maize surplus in Oromia regional state, Ethiopia 
(Doctoral dissertation, Sokoine University of Agriculture). 2014. http://hdl. handle.net/123456789/592. Accessed July 2018.

11. Asfaw S, Shiferaw B, Simtowe F, Haile MG. Agricultural technology adoption Seed access constraints and commercialization in Ethiopia. J Dev Agric Econ. 2011;3(9):436477.

12. Chapoto A, Madison A, Bonsu A. Agricultural commercialization, land expansion and homegrown large-scale farmers: insights from Ghana. 2013. http://www.ifpri.org/sites/default/files/publications/ifpridp012 86.pdf.

13. Gebremedhin B, Jaleta M, Hoekstra D. Smallholders, institutional services, and commercial transformation in Ethiopia. Agric Econ. 2009;40(s1):77387. https://doi.org/10.1111/j.1574-0862.2009.00414.x.

14. Khonje M, Manda J, Alene AD, Kassie A. Analysis of adoption and impacts of improved maize varieties in eastern Zambia. World Dev. 2015;66:695706. https://doi.org/10.1016/j.worlddev.2014.09.008.

15. Tiamiyu S, Akintola J, Rahji M. Technology adoption and productivity difference among growers of new rice for Africa in Savanna Zone of Nigeria. Tropicultura. 2009;27(4):193-7.

16. Yesuf M, Köhlin G. Market imperfections and farm technology adoption decisions - a case study from the highlands of Ethiopia. 2009. http://hdl. handle.net/2077/21494.

17. Alene AD, Manyong V, Omanya G, Mignouna H, Bokanga M, Odhiambo G. Smallholder market participation under transactions costs: maize supply and fertilizer demand in Kenya. Food Policy. 2008;33(4):318-28. https:// doi.org/10.1016/j.foodpol.2007.12.001.

18. Asfaw S, Shiferaw B, Simtowe F. Does technology adoption promote commercialization? Evidence from chickpea technologies in Ethiopia. In: CSAE 2010 conference on Economic Development in Africa, University of Oxford, UK. 2010.

19. Awotide BA, Karimov AA, Diagne A. Agricultural technology adoption, commercialization and smallholder rice farmers' welfare in rural Nigeria. Agric Food Econ. 2016. https://doi.org/10.1186/s40100-016-0047-8.

20. Woolridge JM. Econometric analysis of cross section and panel data. Cambridge: Mit Press; 2010.

21. Feder $G$, Just RE, Zilberman D. Adoption of agricultural innovations in developing countries: a survey. Econ dev cul chan. 1985;33(2):255-98.

22. Burke WJ. Fitting and interpreting Cragg's tobit alternative using Stata. Stata J. 2009;9(4):584. https://doi.org/10.1177/1536867X0900900405.

23. De Janvry A, Sadoulet E. World poverty and the role of agricultural technology: direct and indirect effects. J Dev Stud. 2002;38(4):1-26. https:// doi.org/10.1080/00220380412331322401.

24. Pavelescu FM. Some aspects of the translog production function estimation. Rom J Econ. 2011;32(1):41.

25. Key N, Sadoulet E, Janvry AD. Transactions costs and agricultural household supply response. Am J Agric Econ. 2000;82(2):245-59. https://doi. org/10.1111/0002-9092.00022

26. Sadoulet E, De Janvry A. Quantitative development policy analysis. Baltimore: Johns Hopkins University Press; 1995. http://www.master-eddee.fr/ wp-content/uploads/2011/12/Sadoulet_de-Janvry-QDPA.pdf.

27. Poulton C, Gibbon P, Hanyani-Mlambo B, Kydd J, Maro W, Larsen MN, Osorio A, Tschirley D, Zulu B. Competition and coordination in liberalized African cotton market systems. World Dev. 2004;32(3):519-36.

28. Goetz SJ. A selectivity model of household food marketing behavior in sub-Saharan Africa. Am J Agric Econ. 1992;74(2):444-52. https://doi. org/10.2307/1242498.

29. Singh I, Squire L, Strauss J. Agricultural household models: extensions, applications, and policy. Baltimore: Johns Hopkins University Press; 1986.

30. Rosenbaum PR, Rubin DB. The central role of the propensity score in observational studies for causal effects. Biometrika. 1983;70(1):41-55. https://doi.org/10.1093/biomet/70.1.41.

31. Maddala GS, Nelson F. Switching regression models with exogenous and endogenous switching. In: Paper presented at the Proceedings of the American Statistical Association. 1975.
32. Carter MR, Barrett CB. The economics of poverty traps and persistent poverty: an asset-based approach. J Dev Stud. 2006;42(2):178-99. https:// doi.org/10.1080/00220380500405261.

33. Di Falco S, Yesuf $M$, Kohlin $G$, Ringler $C$. Estimating the impact of climate change on agriculture in low-income countries: household-level evidence from the Nile Basin, Ethiopia. Environ Res Econ. 2012;4:457-78.

34. Hagos F, Holden S. Rural household poverty dynamics in northern Ethiopia 1997-2000: analysis of determinants of poverty. In: Paper presented at the chronic poverty research centre international conference, Manchester. 2003. http://www.albacharia.ma//RuralHouseholdPovertyDyna micsinNorthernEthiopia.pdf? Accessed 20 June 2015.

35. Gurara DZ, Larson DF. The demand for fertilizer when markets are incomplete: evidence from Ethiopia. In: Otsuka K, Larson D (eds) An African green revolution. Dordrecht: Springer; 2013. pp 243-59. https://doi. org/10.1007/978-94-007-5760-8_11

36. Gebregziabher G, Holden S. Does irrigation enhance and food deficits discourage fertilizer adoption in a risky environment? Evidence from Tigray, Ethiopia. J Dev Agric Econ. 2011;3(10):514-28.

37. Yu B, Nin-Pratt A, Funes J, Gemessa SA. Cereal production and technology adoption in Ethiopia. In: Ethiopia strategy support program II (ESSP II). ESSP II working paper. 2011; 1 .

38. Asfaw A, Admassie A. The role of education on the adoption of chemical fertilizer under different socioeconomic environments in Ethiopia. Agric Econ. 2004;30(3):215-28. https://doi.org/10.1111/j.1574-0862.2004.tb001 90.x.

39. Holden ST, Westberg NB. Exploring technology use under climate risk and shocks through an experimental lens. Afr J Agric Res Econ. 2016;11:47-62. https://ageconsearch.umn.edu/record/233848.

40. Alem Y, Bezabih M, Kassie M, Zikhali P. Does fertilizer use respond to rainfall variability? Panel data evidence from Ethiopia. Agric Econ. 2010:41(2):165-75. https://doi.org/10.1111/j.1574-0862.2009.00436.x.

41. Matuschke I, Mishra RR, Qaim M. Adoption and impact of hybrid wheat in India. World Dev. 2007;35(8):1422-35. https://doi.org/10.1016/j.world dev.2007.04.005.

42. Shiferaw B, Kassie M, Jaleta M, Yirga C. Adoption of improved wheat varieties and impacts on household food security in Ethiopia. Food Policy. 2014;44:272-84. https://doi.org/10.1016/j.foodpol.2013.09.012.

43. Wale E, Chianu J. Farmers' demand for extra yield from improved Tef [(Eragrostis tef (Zucc.) Trotter] varieties in Ethiopia: implications for crop improvement and agricultural extension. J Agric Sci Technol. 2015;17(6):1449-62.

44. Gebregziabher G, Namara RE, Holden S. Poverty reduction with irrigation investment: an empirical case study from Tigray, Ethiopia. Agric Water Manage. 2009;96(12):1837-43. https://doi.org/10.1016/j.agwat 2009.08.004

45. Bezu S, Kassie GT, Shiferaw B, Ricker-Gilbert J. Impact of improved maize adoption on welfare of farm households in Malawi: a panel data analysis. World Dev. 2014;59:120-31.

46. Amare M, Shiferaw B. Nonfarm employment, agricultural intensification and productivity change: empirical findings from Uganda. Agric Econ. 2017:48(S1):59-72. https://doi.org/10.1111/agec.12386.

47. Katangese SP, Holden ST, Fisher M. Use of integrated soil fertility management technologies in Malawi: impact of dry spells exposure. Ecol Econ. 2019;156:134-52. https://doi.org/10.1016/j.ecolecon.2018.09.018.

\section{Publisher's Note}

Springer Nature remains neutral with regard to jurisdictional claims in published maps and institutional affiliations. 